\title{
The Impact of Business Excellence on Operational Performance among Halal Certified Food Manufacturers in Malaysia
}

\author{
Nor Ratna Masrom ${ }^{1}$, Raja Zuraidah Raja Mohd Rasi², Badru At Tamam Daut ${ }^{3}$ \\ ${ }^{1}$ Faculty of Technology Management and Technoprenuership, Universiti Teknikal Malaysia Melaka, Melaka, \\ Malaysia \\ ${ }^{2,3}$ Faculty of Technology Management and Business, Universiti Tun Hussein Onn Malaysia, Johor, Malaysia
}

\begin{abstract}
The impact of business excellence with key elements embedded can be a tool for organization to determine opportunities and gain knowledge. This will help the organization to learn how to adopt highperformance and achieve competitive advantage. Through the business excellence model, the organization can execute their strategies to determine, forecast and survive in highly competitive market. This paper presents on identifying those elements in business excellence model (leadership, strategy and planning, customer focus, measurement, analysis, and knowledge management, operation focus) that impact on operational performance in halal certified food manufacturers in Malaysia. Data for the study were collected from 100 halal certified food manufacturers and the relationship proposed in the framework were tested using structural equation modelling (SEM). The result indicated that all the elements of Business Excellence cannot lead to operational performance except for customer focus.
\end{abstract}

\section{Introduction}

The challenge in today's world provides a place full of opportunities for the organizations but highly competitive. Halal product industry is highly in demand because Islam is the world's second largest religion (Hill, 2008). In the year 2010, the world's Muslim population is approximately around 1.6 billion, and this number is expected to increase by $19.8 \%$ to $20 \%$ in 2050 (DeSilver, D and Masci D,201). The global Halal food market is currently one of the fastest growing market segments. Malaysia is one of the world leader in halal food producer. In order for Malaysian to sustain as a world leader in halal food industry, they must continuously differentiate themselves from the competitors. The implementation of Business Excellence (BE) with key elements embedded can serve as a tool to find out their strengths and weaknesses. The Malcolm Baldrige National Quality Award (MBNQA) model is one of the most globally used and proven excellence models for quality awards and self-assessment (Samuelsson and Nilsson, 2002). BE focuses on developing and strengthening the management systems and processes of an organization, which further leads to the improvement of performance, thus, creating value for investors. BE emphasizes on attaining excellence in all aspects of an organization which includes leadership, strategy and planning, customer focus, measurement, analysis, and knowledge management (MAKM), workforce focus and operation focus. Additionally, achieving superior business results is the ultimate goal. MBNQA functioned to recognize companies that show outstanding performances. The MBNQA model which is the basis of US quality award now functions as a foundation for quality awards in many countries including Malaysia. It continuously concentrates on the improvement of all components of the organization, which includes tasks and activities at any level (Nabitz and Klazinga, 1999).

NIST has provided an easy-to-use questionnaire that will help the organization to learn what to improve the performance of their organization. This questionnaire is already proven as an effectiveness of BE and selfassessment is the rigor and effectiveness of the implementation process at all organizational levels.

The aim of this paper is to explore the impact of BE on operational performance in halal certified food manufacturers in Malaysia. The importance of the research lies in the placing of Malaysia as an international business hub seeking to achieve quality and excellence to gain and maintain competitive advantage and to diversify from halal food industry. One of the five guiding principles of the Malaysian strategic plan (2007-2015) is that of implementing public sector excellence.

This paper consists of four sections. Section 2 presents MBNQA model, Section 3 is. The results of a survey conducted in a number of halal certified food manufacturers in Malaysia Finally, Section 4 presents some concluding remarks, as well as future research in the context of the MBNQA model

*Corresponding author: norratna@utem.edu.my 


\section{Self-Assessment}

Organizations need to start self-assessment process include: find the strengths and weakness of the BE embedded elements and how to improve it; provide new motivation for the improvement process and to manage the business (van der Wiele et al. (1996)).

\subsection{MBNQA}

The MBNQA was established in 1987 by the US government as a statement of national intention to provide quality leadership and improve the competitiveness of the USA companies. The National Institute of Standards and Technology (NIST) responsible to manage the award, with the American Society for Quality assisting with the application review process, preparation of award documents and other tasks. MBNQA perceives proceeds with change that can enhance the execution and intensity, and how it can share data adequately on execution procedures. MBNQA is a system that manage the organization and key activities processes to get results. There are seven criteria categories that are designed to endow organizations with an integrated approach to performance excellence. These criteria categories are (1) leadership, (2) strategic planning, (3) customer and market focus, (4) measurement, analysis, and knowledge management, (5) workforce focus, (6) operation focus, and (7) results. In the mid-1990s there was a change in terminology from "quality" and "TQM" to organizational (or business) excellence in the West with the previously called "Quality or TQM Models" being rebranded as business excellence models (Adebanjo, 2001).

Business excellence (BE) can be defined as "excellence in strategies, business practices, and stakeholder-related performance results that have been validated by assessments using proven business excellence models (BEMs)" (Adebanjo and Mann, 2008, p. 1).

The MBNQA BE model self-assesment questionnaire was derived from "are we making progress as a leader?" that provided in the NIST website. The criteria, description and sub-criteria of MBNQA BE model as in table 1 shown below.

Table 1: description and sub-criteria of MBNQA BE model

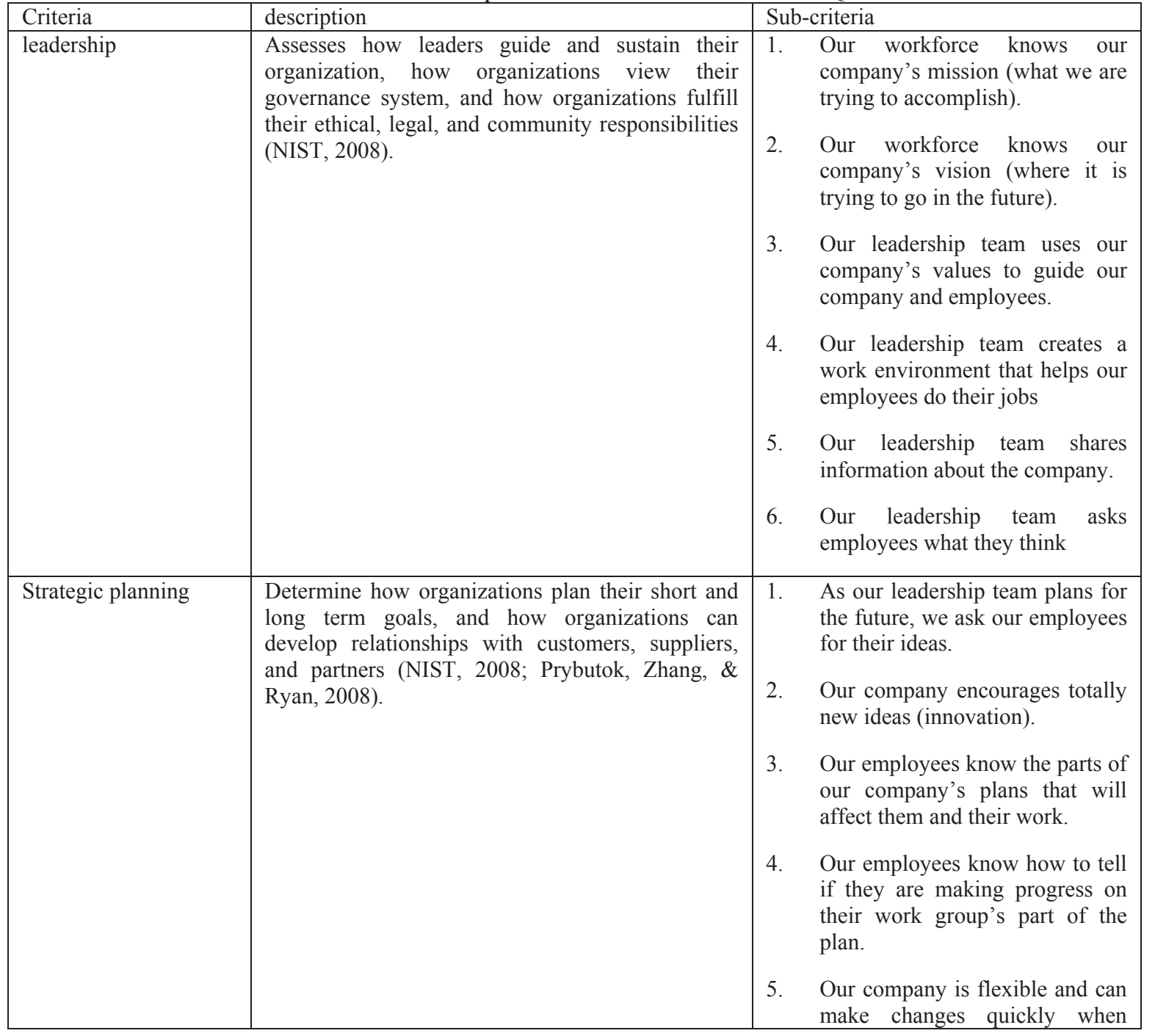




\begin{tabular}{|c|c|c|c|}
\hline & & & needed. \\
\hline Customer focus & $\begin{array}{l}\text { Examine how organizations figure out their } \\
\text { product and service expectations, identify customer } \\
\text { groups and market segments, and determine } \\
\text { customer satisfaction levels to ensure the } \\
\text { continuing relevance of product and service and to } \\
\text { develop new business opportunities (NIST, 2008; } \\
\text { Prybutok et al., 2008). }\end{array}$ & 1. & $\begin{array}{l}\text { Our employees know who their } \\
\text { most important customers are. } \\
\text { Our employees regularly ask } \\
\text { their customers what they need } \\
\text { and want. } \\
\text { Our employees ask if their } \\
\text { customers are satisfied or } \\
\text { dissatisfied with their work. } \\
\text { Our employees are allowed to } \\
\text { make decisions to solve } \\
\text { problems for their customers. } \\
\text { Our employees also know who } \\
\text { our company's most important } \\
\text { customers are. }\end{array}$ \\
\hline MAKM & $\begin{array}{l}\text { Figure out how the organization's selection, } \\
\text { gathering, analysis, management, and improvement } \\
\text { of data, information, knowledge, and information } \\
\text { technology. Also examines how organizations use } \\
\text { review to improve their performance (NIST, 2008). }\end{array}$ & 5. & $\begin{array}{l}\text { Our employees know how to } \\
\text { measure the quality of their } \\
\text { work. } \\
\text { Our employees use this } \\
\text { information to make changes that } \\
\text { will improve their work. } \\
\text { Our employees know how the } \\
\text { measures they use in their work } \\
\text { fit into our company's overall } \\
\text { measures of improvement. } \\
\text { Our employees get all the } \\
\text { information they need to do their } \\
\text { work. } \\
\text { Our employees know how our } \\
\text { company as a whole is doing. }\end{array}$ \\
\hline Workforce focus & $\begin{array}{l}\text { Examines organization's ability to manage, } \\
\text { develop, and assess its workforce. The workforce } \\
\text { will achieve its overall mission, strategy, and } \\
\text { action plans (NIST, 2008). }\end{array}$ & $\begin{array}{l}4 . \\
5 . \\
6 .\end{array}$ & $\begin{array}{l}\text { Our employees cooperate and } \\
\text { work as a team. } \\
\text { Our leadership team encourages } \\
\text { and enables our employees to } \\
\text { develop their job skills so they } \\
\text { can advance in their careers. } \\
\text { Our employees are recognized } \\
\text { for their work. } \\
\text { Our company has a safe } \\
\text { workplace. } \\
\text { Our managers and our company } \\
\text { care about our workforce. } \\
\text { Our workforce is committed to } \\
\text { our company's success. }\end{array}$ \\
\hline Operation focus & $\begin{array}{l}\text { Examines how organizations determine their core } \\
\text { competencies and work systems, and how they } \\
\text { design, manage and improve their key processes to } \\
\text { implement those work systems (NIST, 2008). }\end{array}$ & 1. & $\begin{array}{l}\text { Our employees can get } \\
\text { everything they need to do their } \\
\text { jobs. } \\
\text { Our company has good processes } \\
\text { for doing its work. } \\
\text { Our employees have control over } \\
\text { their personal work processes. } \\
\text { Our company is prepared to } \\
\text { handle an emergency }\end{array}$ \\
\hline
\end{tabular}




\begin{tabular}{|c|c|c|}
\hline & & $\begin{array}{l}\text { 5. We have well established } \\
\text { methods to measure the quality } \\
\text { of our products. } \\
\text { 6. We work closely with our } \\
\text { suppliers to improve each other's } \\
\text { processes. } \\
\text { 7. We have site-wide standardized } \\
\text { and documented operating } \\
\text { procedures. }\end{array}$ \\
\hline
\end{tabular}

\subsection{Operational Performance}

The operational performance is a non-financial indicator that can measure non-financial measures can overcome the limitations of just using financial performance measures (Neely, 1999; Beamon, 1999; Merodi and Steeple, 2000). Operational performance can assess the efficiency and effectiveness of the operations within the firm. These categories of performance reflect competencies in specific areas of the supply chain, including cost, delivery speed and reliability, quality, and customer satisfaction. In measuring firm performance, much attention has been devoted to three aspects: financial, organizational, and strategic performance (Claro, 2004). Organizational theory offers three approaches to measure organizational performance, namely the goal-based, systems and multiple constituency approach. In addition, operational (non-financial) performance measures, such as product quality, customer satisfaction and market share are also frequently examined (Claro, 2004; Soboh et al., 2009). In this study, non-financial indicators are used to measure the performance of halal food operational namely as Compliance with the MS1500 standard and product standard that has been set by the companies, production efficiency and productivity, delivery and food quality.

Table 2: Description of Operational Performance

\begin{tabular}{|c|c|c|}
\hline Criteria & Description & Sub-criteria \\
\hline $\begin{array}{l}\text { Operational } \\
\text { performance }\end{array}$ & 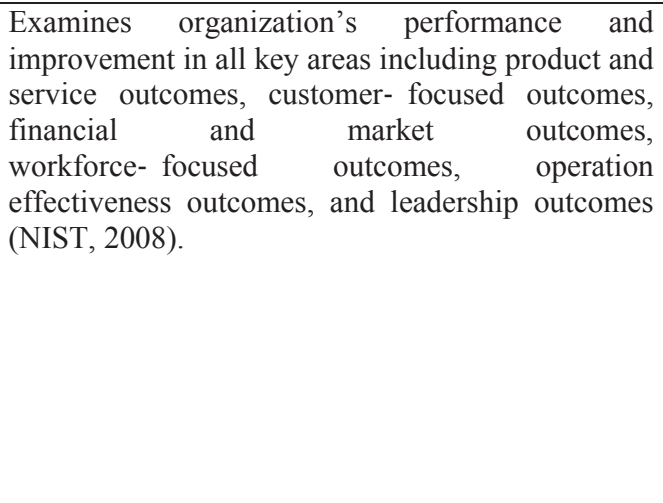 & $\begin{array}{l}\text { 1. Maintenance of consistent } \\
\text { compliance with legislative \& } \\
\text { regulatory requirements MS1500 } \\
\text { 2. Production efficiency } \\
\text { 3. On time delivery } \\
\text { 4. Increased Productivity } \\
\text { 5. Conformity of the product to the } \\
\text { standard } \\
\text { Food quality - Tasty, healthy } \\
\text { and smell }\end{array}$ \\
\hline
\end{tabular}

\subsection{Hypothesis development}

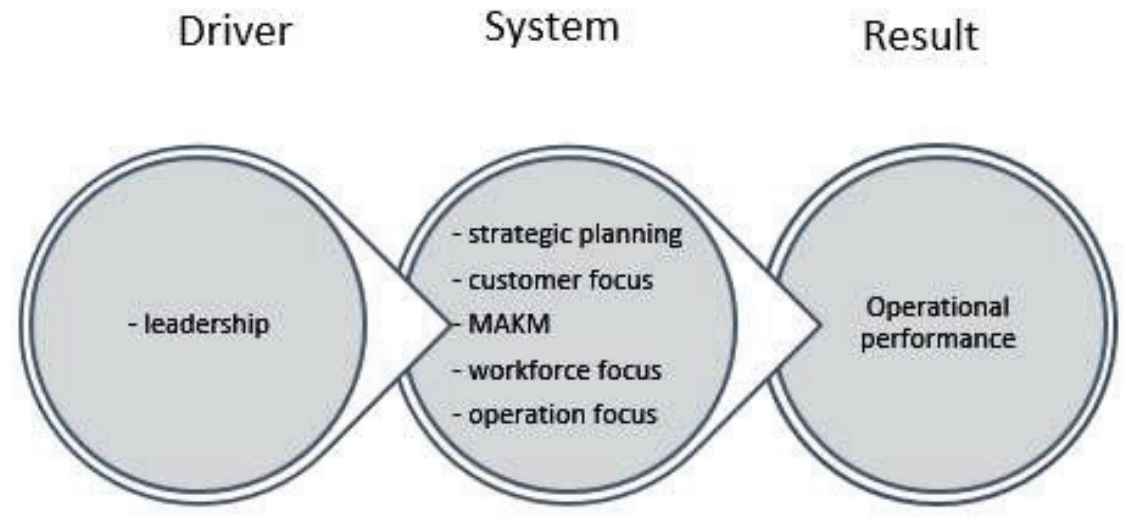

Figure 1: The elements of the general theory in the relationships of the MBNQA BE model (Flynn and Saladin, 2001) 
Table 3: the elements of the general theory in the relationships of the MBNQA BE model.

\begin{tabular}{|l|l|}
\hline MBNQA BE model criteria & Category \\
\hline Leadership & Driver \\
\hline Strategic planning & System \\
Customer focus & \\
MAKM & \\
Workforce focus & \\
Operation focus & \\
& \\
\hline Operational performance & Result \\
\hline
\end{tabular}

Table 4: The causal relationships supposed by the conceptual model (hypotheses)

\begin{tabular}{|c|c|}
\hline \multicolumn{2}{|r|}{ Hypotheses group 1 (H1): Driver criteria influences the system criteria } \\
\hline H1a & Leadership has causal positive effect on Strategic planning \\
\hline $\mathrm{H} 1 \mathrm{~b}$ & Leadership has causal positive effect on customer focus \\
\hline $\mathrm{H} 1 \mathrm{c}$ & Leadership has causal positive effect on MAKM \\
\hline H1d & Leadership has causal positive effect on workforce focus \\
\hline $\mathrm{H} 1 \mathrm{e}$ & Leadership has causal positive effect on operation focus \\
\hline \multicolumn{2}{|r|}{ Hypotheses group 2 (H2): There are interrelationships within system criteria } \\
\hline $\mathrm{H} 2 \mathrm{a}$ & Strategic planning has causal positive effect on customer focus \\
\hline $\mathrm{H} 2 \mathrm{~b}$ & Strategic planning has causal positive effect on MAKM \\
\hline $\mathrm{H} 2 \mathrm{c}$ & Strategic planning has causal positive effect on workforce focus \\
\hline $\mathrm{H} 2 \mathrm{~d}$ & Strategic planning has causal positive effect on operation focus \\
\hline $\mathrm{H} 2 \mathrm{e}$ & Customer focus has causal positive effect on MAKM \\
\hline $\mathrm{H} 2 \mathrm{f}$ & Customer focus has causal positive effect on workforce focus \\
\hline $\mathrm{H} 2 \mathrm{~g}$ & Customer focus has causal positive effect on operation focus \\
\hline $\mathrm{H} 2 \mathrm{~h}$ & MAKM has causal positive effect on workforce focus \\
\hline $\mathrm{H} 2 \mathrm{i}$ & MAKM has causal positive effect on operation focus \\
\hline $\mathrm{H} 2 \mathrm{j}$ & Workforce focus has causal positive effect on operation focus \\
\hline \multicolumn{2}{|r|}{ Hypotheses group 3 (H3): Leader criteria influences the operational performance } \\
\hline $\mathrm{H} 3$ & Leadership has causal positive effect on operational performance \\
\hline \multicolumn{2}{|r|}{ Hypotheses group 4 (H4): System criteria influences the operational performance } \\
\hline $\mathrm{H} 4 \mathrm{a}$ & Strategic planning has causal positive effect on operational performance \\
\hline $\mathrm{H} 4 \mathrm{~b}$ & Customer focus has causal positive effect on operational performance \\
\hline $\mathrm{H} 4 \mathrm{c}$ & MAKM has causal positive effect on operational performance \\
\hline $\mathrm{H} 4 \mathrm{~d}$ & Workforce focus has causal positive effect on operational performance \\
\hline $\mathrm{H} 4 \mathrm{e}$ & Operation focus has causal positive effect on operational performance \\
\hline
\end{tabular}

\section{Methodology}

\subsection{Content validity}

The literature reviews have been conducted. The pilot survey also has been done by giving the questionnaire to the experts from both areas academic and industry. Then, if any comments the amendment was being done to improve the content and clarity of the survey. Lastly, the final version was completed. Besides that, the Malay language version was also being translated and reviewed parallel.

\subsection{Measurement Reliability}

Cronbach's alpha is one of the most popular methods to assess the reliability (Rosnow and Rosenthal 1998). The value of alpha shows the relations among the measurement indicators which with higher correlations among the indicators is the higher of alpha value (Pedhazur and Schmelkin 1991). A value of alpha ranges from 0 to 1 and the higher the alpha the higher the reliability. Table 5 shows the value of Cronbach's alpha, composite reliability and average variance value for each indicator in the research model. 
Table 5: Cronbach's alpha, CR and AVE value.

\begin{tabular}{|c|c|c|c|}
\hline & $\begin{array}{c}\text { Cronbach's } \\
\text { Alpha }\end{array}$ & \begin{tabular}{|c|} 
Composite \\
Reliability (CR)
\end{tabular} & $\begin{array}{c}\text { Average } \\
\text { Variance } \\
\text { Extracted } \\
\text { (AVE) }\end{array}$ \\
\hline Leadership & 0.82 & 0.88 & 0.66 \\
\hline Strategy & 0.67 & 0.86 & 0.75 \\
\hline Customer Focus & 0.71 & 0.83 & 0.63 \\
\hline MAKM & 0.76 & 0.86 & 0.68 \\
\hline Workforce Focus & 0.8 & 0.87 & 0.62 \\
\hline Operation Focus & 0.85 & 0.89 & 0.63 \\
\hline Operational Performance & 0.81 & 0.88 & 0.64 \\
\hline
\end{tabular}

Besides Cronbach's alpha, Werts et al. (1974) developed the composite reliability in assessing the reliability for a set of indicators. The composite reliability is "a closer approximation under the assumption that the parameter estimates are accurate" (Chin 1998). The reliability assessment using the composite reliability generated from SmartPLS. And the threshold value must be higher than 0.70 (Nunnally and Berbstein 1994). In table 5 it is clearly showed that composite reliabilities are above 0.70 . The lowest value is strategy planning, which is 0.86 . However, the values are still at acceptable range. Since both values meet the specification, thus, the measurement instrument of this study is reliable.

\subsection{Measurement Validity}

In this study, all constructs are reflective. Table 21 shows the factors loading, Cronbach alpha, CR and AVE values for all constructs. Fornell and Larcker (1981) suggested that AVE should be above 0.5 to achieve convergent and discriminant validities. It means that when the value at 0.5 , at least $50 \%$ of more variance of the indicators should be accounted for the measured construct. Strategy planning gives the highest value of AVE at 0.75 and all other indicators are above 0.5 , the suggested threshold for the validity test. Therefore, all indicators are at adequate convergent and discriminant validities.

Table 6: Value Of Outer Loading Of Initial Model

\begin{tabular}{|l|l|l|l|l|l|}
\hline construct & Item & $\begin{array}{l}\text { Outer } \\
\text { loading }\end{array}$ & $\begin{array}{l}\text { Cronbach } \\
\text { Alpha }\end{array}$ & CR & AVE \\
\hline leadership & L1 & 0.79 & 0.82 & 0.88 & 0.66 \\
\hline & L2 & 0.81 & & & \\
\hline & L3 & 0.83 & & & \\
\hline & L4 & 0.66 & & & \\
\hline & L5 & 0.68 & & & \\
\hline & L6 & 0.66 & & & \\
\hline strategy & S1 & 0.68 & 0.67 & 0.86 & 0.75 \\
\hline & S2 & 0.69 & & & \\
\hline & S3 & 0.71 & & & \\
\hline & S4 & 0.78 & & & \\
\hline & S5 & 0.67 & & & \\
\hline $\begin{array}{l}\text { Customer } \\
\text { focus }\end{array}$ & C1 & 0.75 & & & \\
\hline & C2 & 0.57 & & & \\
\hline & C3 & 0.69 & & & \\
\hline & C4 & 0.67 & & & \\
\hline & C5 & 0.79 & & & \\
\hline MAKM & M1 & 0.7 & 0.76 & 0.86 & 0.68 \\
\hline & M2 & 0.81 & & & \\
\hline & M3 & 0.79 & & & \\
\hline
\end{tabular}




\begin{tabular}{|l|l|l|l|l|l|}
\hline construct & Item & $\begin{array}{l}\text { Outer } \\
\text { loading }\end{array}$ & $\begin{array}{l}\text { Cronbach } \\
\text { Alpha }\end{array}$ & CR & AVE \\
\hline & M4 & 0.74 & & & \\
\hline & M5 & 0.74 & & & \\
\hline $\begin{array}{l}\text { workforce } \\
\text { focus }\end{array}$ & W1 & 0.76 & 0.8 & 0.87 & 0.62 \\
\hline & W2 & 0.73 & & & \\
\hline & W3 & 0.65 & & & \\
\hline & W4 & 0.6 & & & \\
\hline & W5 & 0.74 & & & \\
\hline & W6 & 0.77 & & & \\
\hline $\begin{array}{l}\text { operation } \\
\text { focus }\end{array}$ & O1 & 0.77 & 0.85 & 0.89 & \\
\hline & O2 & 0.79 & & & \\
\hline & O3 & 0.68 & & & \\
\hline & O4 & 0.75 & & & \\
\hline & O5 & 0.79 & & & \\
\hline & O6 & 0.78 & & & \\
\hline & O7 & 0.69 & & & \\
\hline $\begin{array}{l}\text { Operational } \\
\text { performance }\end{array}$ & OP1 & 0.68 & 0.81 & & \\
\hline & OP2 & 0.83 & & & \\
\hline & OP3 & 0.71 & & & \\
\hline & OP4 & 0.82 & & & \\
\hline & OP5 & 0.79 & & & \\
\hline & & & & & \\
\hline
\end{tabular}

Higher outer loadings indicate that the particular indicators have much in common. The outer loading must be 0.70 or above. (Hair et al., 2013) Those below the value have to be removed. However, after removing indicators, the value of composite reliability as well as on the construct's content validity must be considered. The outer loading analysis removes weak indicators from the model.

Table 7: Value of Outer Loading of Modified Model

\begin{tabular}{|c|c|c|c|c|c|}
\hline construct & Item & $\begin{array}{l}\text { Outer } \\
\text { loading }\end{array}$ & $\begin{array}{l}\text { Cronbach } \\
\text { Alpha }\end{array}$ & CR & $\mathrm{AVE}$ \\
\hline \multirow[t]{5}{*}{ leadership } & L1 & 0.87 & 0.83 & 0.9 & 0.75 \\
\hline & L2 & 0.86 & & & \\
\hline & L3 & 0.85 & & & \\
\hline & L4 & Deleted & & & \\
\hline & L5 & Deleted & & & \\
\hline \multirow[t]{5}{*}{ strategy } & $\mathrm{S} 1$ & Deleted & 0.67 & 0.86 & 0.75 \\
\hline & $\mathrm{S} 2$ & Deleted & & & \\
\hline & S3 & 0.85 & & & \\
\hline & $\mathrm{S} 4$ & 0.88 & & & \\
\hline & S5 & Deleted & & & \\
\hline \multirow[t]{5}{*}{ Customer focus } & $\mathrm{C} 1$ & 0.78 & 0.71 & 0.83 & 0.63 \\
\hline & $\mathrm{C} 2$ & Deleted & & & \\
\hline & $\mathrm{C} 3$ & Deleted & & & \\
\hline & $\mathrm{C} 4$ & 0.72 & & & \\
\hline & $\mathrm{C} 5$ & 0.87 & & & \\
\hline \multirow[t]{5}{*}{ MAKM } & M1 & Deleted & 0.8 & 0.87 & 0.63 \\
\hline & M2 & 0.82 & & & \\
\hline & M3 & 0.8 & & & \\
\hline & M4 & 0.78 & & & \\
\hline & M5 & 0.77 & & & \\
\hline \multirow[t]{6}{*}{ workforce focus } & W1 & 0.82 & 0.8 & 0.87 & 0.62 \\
\hline & W2 & Deleted & & & \\
\hline & W3 & 0.73 & & & \\
\hline & W4 & Deleted & & & \\
\hline & W5 & 0.81 & & & \\
\hline & W6 & 0.79 & & & \\
\hline \multirow[t]{3}{*}{ operation focus } & $\mathrm{O} 1$ & 0.85 & 0.79 & 0.87 & 0.70 \\
\hline & $\mathrm{O} 2$ & 0.86 & & & \\
\hline & $\mathrm{O} 3$ & 0.8 & & & \\
\hline
\end{tabular}




\begin{tabular}{|l|l|l|l|l|l|}
\hline construct & Item & $\begin{array}{l}\text { Outer } \\
\text { loading }\end{array}$ & $\begin{array}{l}\text { Cronbach } \\
\text { Alpha }\end{array}$ & CR & AVE \\
\hline & 04 & Deleted & & & \\
\hline & 05 & Deleted & & & \\
\hline Operational performance & OP1 & Deleted & 0.8 & 0.88 & 0.72 \\
\hline & OP2 & 0.89 & & & \\
\hline & OP3 & Deleted & & & \\
\hline & OP4 & 0.86 & & & \\
\hline & OP5 & 0.79 & & & \\
\hline
\end{tabular}

To complete the convergent validity analysis, AVE and CR were revaluated. AVE and CR results in Table 22 are above 0.50 and 0.70 .

\subsection{Discriminant validity}

The discriminant validity of the scales for constructs validity and estimated the internal consistency for reliability was done before assessing the model. In the table 8 shows below the highest value is more than 0.90 and this brings the validity has been established.

Table 8: Heterotrait-Monotrait Ratio of Correlations (HTMT)

\begin{tabular}{|l|r|r|r|r|r|r|}
\hline & Customer & Leadership & MAKM & $\begin{array}{l}\text { Operational } \\
\text { performance }\end{array}$ & Operation & strategy \\
\hline Customer & & & & & & \\
\hline Leadership & 0.68 & & & & & \\
\hline MAKM & 0.73 & 0.79 & & & & \\
\hline $\begin{array}{l}\text { Operational } \\
\text { performance }\end{array}$ & 0.39 & 0.52 & 0.64 & & & \\
\hline Operation & 0.88 & 0.57 & 0.75 & 0.65 & & \\
\hline Strategy & 0.72 & 0.76 & 0.86 & 0.58 & 0.79 & \\
\hline Workforce & 0.77 & 0.51 & 0.5 & 0.52 & 0.82 & 0.68 \\
\hline
\end{tabular}

\subsection{Model of fit}

Model of fit in SMARTPLS was mimicking with CB-SEM. Hair et al., 2017 said that model of fits indices can judge how well a hypothesis model fits the empirical data. As a result, it can help to figure out the misspecification. This research used SRMR to identify the range of model misspecification (Dijkstra \& Henseler, 2015; Henseler et al., 2014). A value less than 0.10 or of 0.08 (in more conventional criteria; see $\mathrm{Hu}$ and Bentler, 1999) are considered a good fit. Henseler et al. (2014) introduce the SRMR as a goodness of fit measure for PLS-SEM that can be used to avoid model misspecification.

Table 9: Model of Fit

\begin{tabular}{|l|ll|l|}
\hline & Saturated Model & Estimated Model \\
\hline SRMR & & 0.08 & 0.10 \\
\hline
\end{tabular}

\subsection{The coefficient of determination ( $R$-squared)}

Table 10: R-squared

\begin{tabular}{|l|r|c|}
\hline & R-squared & Result \\
\hline strategy planning & 0.33 & moderate \\
\hline customer & 0.34 & moderate \\
\hline MAKM & 0.55 & moderate \\
\hline workforce focus & 0.4 & moderate \\
\hline Operation focus & 0.62 & moderate \\
\hline Operational Performance & 0.66 & moderate \\
\hline
\end{tabular}


The coefficient of determination $\left(\mathrm{R}^{2}\right)$ is a measure of the model's predictive accuracy and represents the amount of variance in an endogenous construct explained by all exogenous constructs linked to it. $\mathrm{R}^{2}$ values range from 0 to 1 with higher values indicating higher levels of predictive accuracy. The range for acceptable $\mathrm{R}^{2}$ depends on the type of study. Henseler et al. (2009) indicates that 0.67, 0.33, and 0.19 are substantial, moderate, and weak values. Researchers seek models that are good at explaining the data with high $\mathrm{R}^{2}$ values but also parsimonious with few exogenous constructs. Table 25 summarizes the $\mathrm{R}^{2}$ for model endogenous latent variables; values range between 0.33 and 0.66 reflecting a model with solid predictive accuracy.

\subsection{Hypothesis testing}

Path coefficients are representing the hypothesis of relationships among the constructs. The value is between -1 and +1 . Estimated path coefficients close to +1 represent strong positive relationships. The closer the estimated coefficients are to 0 , the weaker the relationships. Bootstrapping has been used to find out the significant of the coefficient. PLS-SEM also can figure out the relevant effects. The commonly used critical value for the two-tailed $t$-test is 1.96 for significance level of 10 percent (Hair et. al., 2013, p. 171). Table 29 summarizes the leader path coefficients, $t$-values and $p$-values. The combined analysis of path coefficients, original indicates that all path coefficients.

Table 11: Interrelation between Variables

\begin{tabular}{|l|l|l|l|l|l|l|l|}
\hline & Leadership & $\begin{array}{l}\text { Strategic } \\
\text { Planning }\end{array}$ & $\begin{array}{l}\text { Customer } \\
\text { Focus }\end{array}$ & MAKIM & $\begin{array}{l}\text { Workforce } \\
\text { Focus }\end{array}$ & $\begin{array}{l}\text { Operation } \\
\text { Focus }\end{array}$ & $\begin{array}{l}\text { Operational } \\
\text { performance }\end{array}$ \\
\hline Leadeship & - & & & & & & \\
\hline $\begin{array}{l}\text { Strategic } \\
\text { Planning }\end{array}$ & $0.58 / 8.29^{* *}$ & & & & & & \\
\hline $\begin{array}{l}\text { Customer } \\
\text { Focus }\end{array}$ & $0.35 / 3.88^{* *}$ & $0.30 / 2.67^{*}$ & & & & & \\
\hline MAKIM & $0.34 / 3.24^{* *}$ & $0.33 / 2.61^{*}$ & $0.22 / 2.51^{*}$ & & & & \\
\hline $\begin{array}{l}\text { Workforce } \\
\text { Focus }\end{array}$ & $0.006 / 0.52$ & $0.28 / 2.39^{*}$ & $0.44 / 4.86^{* *}$ & $-0.06 / 0.49$ & & & \\
\hline $\begin{array}{l}\text { Operation } \\
\text { Focus }\end{array}$ & $-0.08 / 0.83$ & $0.14 / 1.36$ & $0.28 / 2.46^{*}$ & $0.27 / 2.11^{*}$ & $0.36 / 4.05^{* *}$ & & \\
\hline $\begin{array}{l}\text { Operational } \\
\text { Performance }\end{array}$ & $0.07 / 0.8$ & $0.09 / 1.02$ & $0.17 / 2.05^{*}$ & $0.15 / 1.31$ & $0.09 / 0.86$ & $0 / 0.02$ & \\
\hline R-Square & 0 & 0.33 & 0.34 & 0.55 & 0.4 & 0.62 & \\
\hline
\end{tabular}

Notes: R-squares are shown in bold.

${ }^{2}$ Represent path coefficients.

${ }^{b}$ Represent T-Statistics.

* Significant at the 0.05 level.

*- Significant at the 0.01 level.

The strength of the correlation was assessed through the value of the correlation coefficient, which ranges from -1 to 1 . In this study, given that the correlations were all positive, the range was from 0 to 1 . A coefficient of 0 indicates no correlation, a coefficient of .3 indicates low correlation, a coefficient of .5 indicates medium correlation, and a coefficient of .7 or more indicates a high correlation. 
Table 12: Summarization of result of hypothesis testing

\begin{tabular}{|l|l|l|}
\hline \multicolumn{3}{|c|}{ Hypotheses group 1 (H1): Driver (leadership) criteria influence System Criteria } \\
\hline H1a & Leadership has causal positive effect on Strategic planning & Accepted \\
\hline H1b & Leadership has causal positive effect on customer focus & Accepted \\
\hline H1c & Leadership has causal positive effect on MAKM & Accepted \\
\hline H1d & Leadership has causal positive effect on workforce focus & Rejected \\
\hline H1e & Leadership has causal positive effect on operation focus & Rejected \\
\hline \multicolumn{3}{|l|}{ Hypotheses group 2 (H2): There are interrelationships within system criteria } \\
\hline H2a & Strategic planning has causal positive effect on customer focus & Accepted \\
\hline H2b & Strategic planning has causal positive effect on MAKM & Accepted \\
\hline H2c & Strategic planning has causal positive effect on workforce focus & Accepted \\
\hline H2d & Strategic planning has causal positive effect on operation focus & Rejected \\
\hline H2e & Customer focus has causal positive effect on MAKM & Accepted \\
\hline H2f & Customer focus has causal positive effect on workforce focus & Accepted \\
\hline H2g & Customer focus has causal positive effect on operation focus & Accepted \\
\hline H2h & MAKM has causal positive effect on workforce focus & Rejected \\
\hline H2i & MAKM has causal positive effect on operation focus & Rejected \\
\hline H2j & Workforce focus has causal positive effect on operation focus & Accepted \\
\hline Hypotheses group 3 (H3): System criteria influence Results Criteria (Operational & \\
\hline \multicolumn{2}{|l|}{ Performance) } & \\
\hline H3 & Leadership has causal positive effect on operational performance & Rejected \\
\hline Hypotheses group 4 (H4): System criteria influence Results Criteria (Operational & \\
\hline \multicolumn{2}{|l|}{ Performance) } & Rejected \\
\hline H4b & Strategic planning has causal positive effect on operational performance & Rejected \\
\hline H4c & Customer focus has causal positive effect on operational performance & Rejected \\
\hline H4d & Workforce focus has causal positive effect on operational performance & Rejected \\
\hline H4e & Operation focus has causal positive effect on operational performance \\
\hline
\end{tabular}

Shows that customer focus has relationship with operational performance at $p$-values $<0.05$. While other criteria do not show any significant relationship. Therefore, only H4b is accepted while H4a, H4c, H4d and H4e are rejected.

\section{Implications for managers}

The findings of the current study provide important pointers to managers in terms of managing their organizations for superior performance. First of all, the study establishes that quality management practices are holistic in that they must be effectively linked together for organizational success. Thus, synergies must be created among the best practice factors to achieve favorable results. The study identifies strategic planning and customer focus as the two factors that act as the foundations of these synergies because they have the biggest number of direct effects on the other factors in the system. Therefore, as far as strategic planning is concerned, companies need to properly plan and develop strategies that embrace the organization's focus on quality and assume responsibility for quality and change in all aspects of management including customer relationships, MAKM and workforce focus. In terms of customer focus, organizational resources must be allocated to fulfill the need of the customer. Leadership and MAKM also has implications on a company's operational performance. The effective implementation of practices related to these factors is likely to result in improved performance. MAKM and leadership indirectly affect operational performance mediated through SCI. However, without leadership and the use of MAKM related practices operationalized in this study that affect operational performance through SCI, the impact of operation focus on operational performance may be doomed to fail. Thus, once again, managers must be aware of the significance of synergistic effects in the best practice system. The direct effect of operation focus and MAKM to SCI indicate that these factors have potential to enhance operational performance. This is due to the high impact of material costs on profits, compliance to the standard, on time delivery and operational effectiveness and increasing emphasis on just-in-time production (Sarkis et al., 2002).

\section{Implication for academician}

In the academic context, the current study adds to the body of literature on best practice factors and their impact on business results. This study used an extensive literature review to come up with a set of factors and indicators to measure these factors. In addition, it utilized a comprehensive literature review to formulate 21 hypotheses. Using SEM as a strong methodology to test these hypotheses, it revealed that only 10 of the 21 hypotheses were significant within the best practice system modeled. Therefore, the hypothesized relationships must be examined further in future studies to determine the reasons as to why some of the bivariate relationships that were found to be 
significant in other studies were empirically nonsignificant in the current study. A naive response to this would probably be that the business excellence practices of Malaysian companies are not as complex as the methods espoused by the quality researchers indicating a nonconvergence between theory and practice. However, a more indepth look into this issue would possibly reveal that a more complex set of reasons underlie these discrepancies. For instance, although most of the quality researchers argue that quality management practices are universally applicable, there is also a group of researchers who argue that these practices are contingent upon other factors. As mentioned before, these factors may include firm type (different industries, service vs. manufacturing etc.), and country of origin of companies, which may have implications for the nature of the quality management practices implemented and so on. Therefore, it is important that future studies that test related hypotheses control for these factors in examining direct and indirect effects among factors and indicators. It is possible that these relationships occur in unique ways under different conditions. The results obtained in the current study that were similar to those of Wilson et al. (2000) and Pannirselvam et al. (2001) may suggest that these relationships are universally applicable for firms of different size and type. On the other hand, the differences in the significance of paths across three studies may indicate that the relationships under investigation are contingent upon the differing conditions in which the companies operate. One possible way to test these differences could be through the use of multiple group analyses within a SEM framework, where the significance of paths could be tested using data from different industries, from firms in different countries or even data from firms that have formal quality programs versus those that do not. In addition to testing how the best practice factors affect each other under different conditions, it would be interesting to examine how they are related to business results under such conditions, if at all. Finally, it should also be noted that it is likely for different statistical methods to yield different results regarding the relationships among variables. For instance, a simple correlation analysis (which is what many previous studies used) may indicate that two factors are highly correlated, although this relationship may turn out to be non-significant in a multiple regression or SEM analysis. Therefore, it would probably be a better idea to analyze such relationships within a multivariate framework to get more accurate results.

\section{Acknowledgement}

The author is grateful to Malaysian Ministry of Higher Education (MoHE) under Fundamental Research Grant Scheme (FRGS) to the Office of Research, Innovation, Commercialization and consultancy (ORICC) Universiti Tun Hussein Onn Malaysia (UTHM) under Vot 1430.

\section{References}

1. Desilver, D., 2013. World's Muslim population more widespread than you might think. Pew Research Center, 7.

2. U.W. Nabitz, N.S. Klazinga, (1999) "EFQM approach and the Dutch Quality Award", International Journal of Health Care Quality Assurance, Vol. 12 Issue: 2

3. Dotun Adebanjo, Robin Mann, (2000) "Identifying problems in forecasting consumer demand in the fast moving consumer goods sector", Benchmarking: An International Journal, Vol.7 Issue: 3

4. Ab Rahman, L. (2008, January). Shariah and Malaysia Halal certification system. In Paperwork presented in Halal Food Seminar.

5. Ab Talib, M. S., \& Johan, M. R. M. (2012). Issues in halal packaging: a conceptual paper. International Business and Management, 5(2), 94-98.

6. Ab Talib, M. S., Abdul Hamid, A. B., \& Zulfakar, M. H. (2015). Halal supply chain critical success factors: a literature review. Journal of Islamic Marketing,

7. Backhouse, C. J., \& Sidek, A. A. (2014). Environmental sustainability issues in Malaysian metal and fabrication SMEs: comparative analysis from a case study perspectives.

8. Bahrudin, S. S. M., Illyas, M. I., \& Desa, M. I. (2011, July). Tracking and tracing technology for halal product integrity over the supply chain. In Electrical Engineering and Informatics (ICEEI), 2011 International Conference on (pp. 1-7). IEEE.

9. Bonne, K., \& Verbeke, W. (2008). Religious values informing halal meat production and the control and delivery of halal credence quality. Agriculture and Human Values, 25(1), 35-47.

10. Bovet, D., \& Martha, J. (2000). Value nets: reinventing the rusty supply chain for competitive advantage. Strategy \& Leadership, 28(4), 21-26.

11. Bovet, D., \& Martha, J. (2003). Supply chain hidden profits. Mercer Management Consulting, available at: www. valuenets. com/book/VNPreprint. pdf (accessed 8 August 2003). 